\title{
CATALYSTS OF UNIVERSITY SOCIAL RESPONSIBILITY INTO STRATEGIC PLANNING BY THEMATIC ANALYSIS AND DEDUCTIVE CODING
}

\author{
Elva L. Ramos-Monge \\ Polytechnic University of Catalonia, Department of Management, Barcelona, \\ Spain \\ elva.lizeth.ramos@estudiant.upc.edu \\ Xavier Llinàs-Audet \\ Polytechnic University of Catalonia, Department of Management, Barcelona, \\ Spain \\ xavier.llinas@upc.edu \\ Jesús Barrena-Martínez \\ University of Cadiz, Department of Business Management, Faculty of Economics \\ and Business, Cadiz, Spain \\ jesus.barrena@uca.es
}

\begin{abstract}
The relevance of higher education institutions (HEI) for social development is unquestionable because of their potential for contributing intellectual solutions for the social, economic, and environmental welfare of society. The current study aims to: 1) examine which are the main catalysts of university social responsibility (USR) from a strategic management perspective; 2) show the relations among those catalysts through semantic networks; and 3) analyse the role of university promotion of entrepreneurship. The method uses a content analysis in a sample of 23 universities and examines the subject and codes to clarify the catalysts. The semantic networks are shown to reveal these connections. It was found that a high percentage of universities orient their efforts towards enhancing the employability of students, mainly through entrepreneurial projects intended to achieve social responsibility.
\end{abstract}

Keywords: strategic management, strategic planning, stakeholder theory, higher education institutes, university social responsibility, sustainable entrepreneurship, student employability, university economic management, university cooperation, qualitative research, deductive method.

\section{Biographical notes:}

Elva Lizeth Ramos-Monge is a $\mathrm{PhD}$ student in Business Administration and Management at the Universitat Politècnica de Catalunya (Spain) in the Department of Management. She holds a master's degree in business and economic studies. Her master's thesis was related to student entrepreneurship in Spanish and Mexican universities. Her research focuses on the inclusion of social responsibility in universities, its application, the role of stakeholders, and the integration of social responsibility in university strategy. Her research interests include strategic management, university social responsibility (USR), corporate social responsibility (CSR), qualitative analysis, and university entrepreneurship. She has published a chapter in INTECH entitled 'Universities as corporate entities: the role of social 
responsibility in their strategic management' and an article entitled 'Drivers and barriers of university social responsibility: integration into strategic plans'.

Xavier Llinàs-Audet is a lecturer at the Polytechnic University of Catalonia in the Department of Management (OE). He researches the fields of human capital, competitiveness and innovation, strategic management, economics, business training, higher education management, regional economy, and people management. He specifically explores issues such as the role of training in organisations, managerial skills, and competencies. He has published articles in national and international journals such as Intangible Capital, International Journal of Training and Development, Revista de Educación, and the European Journal of Engineering Education.

Jesús Barrena-Martínez is an assistant lecturer in the Faculty of Business and Economics at the University of Cadiz (Spain). His $\mathrm{PhD}$ dissertation received a special mention from the Santander Chair of Corporate Social Responsibility (CSR) for the best $\mathrm{PhD}$ on CSR in Spain in 2014. He has published in journals such as the International Journal of Human Resource Management, Corporate Social Responsibility, and Environmental Management, Intangible Capital, European Research on Management and Business Economics, European Journal of Management and Business Economics, and Journal of Human Values. His teaching and research interests include human resource management, corporate social responsibility, and intellectual capital.

\section{INTRODUCTION}

The study of university social responsibility (USR) receives considerable academic attention for its contribution to sustainability in terms of social, economic, and environmental impact. To enable that positive impact, higher education institutions (HEI) should consider the integration of USR as part of their strategy. USR can be explained as a policy of ensuring an ethical quality of performance of the university stakeholders through responsible management (Vallaeys 2013). HEI should promote drivers (or catalysts) for USR to achieve this responsible management. These catalysts are understood in this research as the specific actions that academic authorities foster and integrate as part of university activities. In this line, academic authorities should understand, engage, communicate, control, coordinate and lead actions for USR. This task can be helped by using strategic plans as a main tool of academic management (Llinàs et al. 2011) and a bridge between strategic thinking and strategic actions.

The potential of universities to help social development has not been sufficiently explored, although many efforts by many organisations have been made (GRI 2017; GUNI 2017; ISO 26000 2017; PRME 2018). In this work, USR is studied from the university management approach, specifically including USR in strategy and strategic plans to formalise it in HEI. Consequently, considerable interest in this issue arises from the value that social responsibility could bring to social development and the possible answers it may offer to current socioeconomic challenges.

The objectives of this work are to: 1 ) discover which are the main catalysts that universities integrate into strategic plans, and four hypotheses are proposed related to USR catalysts, 2) show relations among catalysts through semantic networks, and 3) analyse how universities promote entrepreneurship to achieve their responsibility to students. To achieve these objectives and to respond to the 
hypotheses, the catalysts were taken from the model of 'USR drivers in Spanish universities' (Ramos-Monge et al. 2017a).

Results show that universities consider USR catalysts in every university dimension. Moreover, connections among catalysts are displayed by means of semantic networks to identify how some catalysts include others. Finally, to achieve the third objective, projects, programmes, and other university activities were identified to discover how they promote entrepreneurship (as 'Promotion of entrepreneurial projects' is a USR catalyst). It is shown that every university in the sample has implemented entrepreneurial activities. It is suggested that universities promote entrepreneurial behaviour by boosting sustainable entrepreneurship, as this type of entrepreneur aims to balance economic health, social equality, and environmental resilience (Hockerts \& Wüstenhagen 2010; Rice et al. 2014; Ratten et al. 2017). Furthermore, it has been identified that the literature supports the promotion of social entrepreneurship in universities in order to offer solutions for social challenges (Ratten \& Welpe 2011).

To develop this work, a thematic analysis and a deductive coding is used. Thematic analysis is a methodology for identifying, analysing, and registering patterns or themes within data (Braun \& Clarke 2006). This process includes the identification of themes through 'careful reading and re-reading of the data' (Rice \& Ezzy 1999). Therefore, 23 strategic university plans were taken as a sample and ATLAS.ti software was used to analyse each strategic plan.

The content of this document is structured as follows. The first section explains the research gap and theoretical framework. Secondly, the manuscript explores the method and validation of the model. The final section presents the results, conclusions, and discussions.

\subsection{Research gap and objectives}

Universities are making important efforts to implement social responsibility. Nevertheless, there is no consensus about which specific activities or catalysts belong to USR and how these activities are interconnected. Moreover, although universities are increasing their efforts to promote entrepreneurial projects (Rothaermel et al. 2007), the link between the USR and university entrepreneurship needs further analysis. Therefore, this research establishes the following objectives:

1. Find the main catalysts of university social responsibility (USR) in strategic plans and give response to hypotheses

2. Represent relations among USR catalysts through semantic networks

3. Analyse the role of university promotion of entrepreneurship.

\section{THEORETICAL FRAMEWORK}

For a better understanding of this issue, it is important to make references to specific subjects such as university strategic management, USR concept, stakeholder theory, USR in strategic plans, and USR catalysts.

\subsection{Strategic management and strategic planning}

In every organisation, strategic management is an essential activity to establish the path to follow, and strategic planning serves for clarifying that direction, establishing priorities, and improving organisational performance (Shah 2013). Strategic management includes a technical team to monitor activities 
related to HEI work by using the strategic plan as a principal management tool (Llinàs et al. 2011).

The USR, as CSR when used strategically, helps create value in the long term as it is more efficient in resource utilisation (Rexhepia et al. 2013). Thus, university strategic management helps academic authorities achieve university missions through strategic decisions (Ramos-Monge et al. 2017b). In this line, it is important to define strategy as 'a system of finding, formulating, and developing a doctrine that will ensure long-term success if followed faithfully' (Kvint 2009). Therefore, it refers to finding an efficient way to achieve the specified objectives. Strategy is also understood as defining the goals and what is needed to achieve these goals (Porter 1980; Porter 1996). Normally, it is expected that universities, as public organisations, pursue social strategies because of their inherent social mission (Vázquez et al. 2016).

Although strategic planning belonged mainly to the private sector until the 1970s (Candy \& Gordon 2011), by the late 1980s strategic planning had emerged in universities as part of an improved management process (Albon et al. 2016). Strategic management is for building and executing HEI goals by academic authorities. In this process, resources and internal and external environments should be considered (Nag et al. 2007). Strategic management normally includes two steps: 1) formulation of a plan, which includes internal and external analysis, strategy formation, and recognition of goals; 2) implementation of a plan, which includes structure (define organisational structure and initiatives) and control and feedback (Mintzberg \& Quinn 1996). Execution or implementation of the plan is usually the most difficult part, this complication is commonly related to several aspects such as lack of autonomy, governance, leadership, stakeholder participation, and managerial talent. This step is difficult because it involves more people and requires a high level of commitment (Hrebiniak 2007).

Success depends on the ability to think strategically. Strategic thinking involves the application of knowledge, intuition, and creativity, the main objective being to determine competitive strategies to position the organisation (Mintzberg 1994).

Strategic thinking and strategic planning should not be confused. Strategic thinking needs intuitive, creative, innovative, and unconventional methods of thinking (Heracleous 1998). However, strategic planning involves an analytical process (Mintzberg 2009) that is often complex and chaotic (Mintzberg 1994).

Increasingly, strategic planning is no longer a well-established process and has been shown as a nonlinear activity (Albon et al. 2016). Communication among university stakeholders is of great importance for carrying out strategic planning. Beyond describing mission, vision, and values, strategic planning must include specific and achievable goals (Cowburn 2005). These goals vary according to each university environment and the resources and needs. To help this task, strategic management arises as a way of improving organisation, increasing competitiveness, and is related from the beginning with the accountability and accreditation standards (Aleong 2007).

\subsubsection{University social responsibility and its background}

To explain social responsibility in universities, it is necessary to clarify essential concepts of university management, since social responsibility arises from the university's administration. Thus, corporate governance processes the relations by which organisations are managed (Shailer 2004) and this represents an 
important starting point. These aspects must be carefully carried out to achieve specific objectives. Consequently, the direction of such actions is the key to achieving the objectives.

In universities, academic authorities will perform that important role, while for companies the principal objective of corporate governance is to protect the owner's interests. Corporate governance in HEI serves to cover the university stakeholder demands. These demands distinguish HEI from private corporations, due to the fact that the university's mission as a public organisation is mainly social (Vázquez et al. 2016).

This corporate governance recognises rights and responsibilities among stakeholders and embraces decision-making process in the organisation (Lin 2013). Without a well-organised university governance, decisions related to social responsibility catalysts (as it is called in this work) could be quite difficult to make.

Once corporate governance is clear, it is important to continue with the emerging concept of USR, which originated in private organisations, specifically when it was recognised that decision-making by businesses affects society (Bowen 1953). The concept of corporate social responsibility (CSR) appeared as a mechanism by which organisations monitor and ensure their activities are legal and ethical (Rasche et al. 2017).

The main theories on CSR have been classified into four groups: 1) instrumental theories that consider social responsibility as an instrument for wealth creation; 2) political theories related to the responsible use of corporate power in the political field; 3 ) integrative theories based on satisfying social demands; and 4) ethical theories founded on ethical responsibilities to society (Garriga \& Melé 2004). However, the difficulties of applying CSR seem to be related to doubts about its benefits. This may be explained as that management will rarely apply CSR without financial benefits (Burke \& Logsdon 1996). Several authors have studied the relationship between CSR and financial strategy and have determined that CSR has a strategic value (Burke \& Logsdon 1996; McWilliams \& Siegel 2001). For universities, the scenario is quite different, universities have a social mission and do not pursue profits.

Considering the description of CSR, USR can be defined as the performance of ethical policy by university stakeholders through responsible management of educational, cognitive, and environmental impacts, and in constant dialogue with society to increase sustainable development (Vallaeys 2013). USR can also be understood as the strategic commitment to society, the recognition of every internal and external stakeholder, and the search for policies that will benefit the stakeholders (UNIBILITY 2017). As mentioned in the introduction, this work is supported by a previous research using the Delphi method (García \& Suárez 2013), which consisted of asking experts about USR. Besides obtaining results related to USR catalysts, there were also important contributions to USR definitions (see Table 1).

Therefore, decision-making by academic authorities affects society, but not in the same way as private companies - and universities are expected to have a positive effect on society by encouraging social, economic, and environmental development and bringing social value. This value makes reference to the degree to which a particular action or planned action is important or useful in relation to something to achieve (Cambridge Dictionary 2017). In this line, it is important to 
note the importance of USR catalysts for achieving the social mission of the university.

University ethical work can be divided into two domains aligned with the university's social character: 1) communicative association, related to civil behaviour, right to speak, justice, solidarity, compassion, tolerance, empathy and dialogue, based on honesty and respect; and 2) the domain of secular intellectual practices related to freedom of intellectual activities, observation, reasoning, research, criticism, and imagining (Marginson 2007). This research is based on the four university impacts: organisational, educative, social, and cognitive (Vallaeys et al. 2009).

Efforts regarding social responsibility focused on promoting ethical actions in both public and private organisations have been mostly oriented by international organisations, who have joined efforts to better define, measure, control and evaluate the subject. Universities have used these sources and tried to adapt them to the particularities of HEI. Some of these organisations are:

- Global Reporting Initiative (GRI) is an international organisation that has developed sustainability reporting, helping private and public organisations to communicate their impacts into issues such as: climate change, human rights, governance, and social well-being (Dumay et al. 2010; GRI 2017). This is the principal standard for reporting information related to social responsibility and one of the most demanding standards (Rueda \& Uribe 2011).

- Global University Network for Innovation (GUNi) is an international network created by the UNESCO, (UNU), and (UPC) which inspires HEI to redefine their role by changing their position within society (GUNI 2017)

- ISO 26000 Social Responsibility, as an international standard that helps all public or private organisations, regardless of their size, to develop a responsible management, following principles regarding human rights, labour practices, the environment, fair operating practices, consumer issues and, community involvement and development (ISO 26000 2017).

- Principles for Responsible Management Education (PRME)

Created under the coordination of the UN Global Compact and key academic institutions, PRME developed six principles: 1) develop student capabilities for business and society; 2) university promotion of values related to global social responsibility; 3) improve educational methods for effective learning and responsible leadership; 4) encourage research about the role, dynamics, and impact of corporations in the creation of sustainable social, environmental, and economic value; 5) create networks with business managers to learn more about the challenges in meeting social and environmental responsibilities; and 6) promote communication among university stakeholders on issues related to global social responsibility and sustainability (PRME 2018).

Likewise, other organisations such as the Catalan Association of Public Universities (ACUP) and the Catalan Agency for Development and Cooperation in coordination with other Catalan universities have joined efforts to engage universities with the Sustainable Development Goals (USDG 2017).

\subsubsection{Stakeholder theory}


USR implementation needs efforts by academic authorities in recognising groups involved or affected by HEI activities, and without this recognition it could be difficult to state strategic actions in reply to their demands. Thus, stakeholder theory explains and supports USR (Larrán Jorge \& Andrades Peña 2015).

The university community includes multiple stakeholders: students and families; university administrative staff and faculty members; suppliers of goods and services; educational sector; other universities; commerce and industry (Reavill 1998). Stakeholders have also been classified as internal or external (Burrows 1999; Jongbloed et al. 2008). Some authors agree that not all stakeholders are equally important, and this is explained by the stakeholder level of influence according to the theory of stakeholder salience (Mitchell, R. K., Agle, B. R., \& Wood 1997). This theory distinguishes those stakeholders with an urgency for immediate actions, influence, or power in the development of specific actions; and the legitimacy of the activities that the institution performs.

In the case of universities, students claim special attention because they tend to be the main clients of HEI (Sánchez \& Mainardes 2016). Initiatives such as the Principles for Responsible Management Education (PRME) focus attention on improving student training by promoting student values in business schools.

\subsubsection{Catalysts of university social responsibility}

To address the strategic actions taken by academic authorities to achieve USR, this paper took a model of USR catalysts obtained from the study entitled 'Drivers and barriers of university social responsibility: integration into strategic plans' (Ramos-Monge et al. 2017a).

This study used a Delphi method, which consists of giving several iterations of questionnaires to experts on a USR topic, with each questionnaire modified according to the feedback provided by experts in previous iterations. This study considered 27 experts from Spanish and Mexican universities and a questionnaire was applied with a Likert scale and open questions. The objective was to achieve expert consensus (Linstone \& Turoff 1975).

As a result of the Delphi method, a USR catalyst model was obtained (see Table 2). The model is divided into four dimensions and each has separate groups of catalysts (as actions with a more general concept) and sub-catalysts (more specific actions to look for USR). Every group of USR catalysts was chosen based on a literature review, and dimensions were developed based on the university impacts suggested by Vallaeys et al. 2009: (1) the organisational dimension includes staff, lecturers, and university suppliers, as described in this study; (2) the organisational dimension includes ethical and environmental management, as well as management staff; (3) the educational dimension includes the impact on students; (4) the cognitive dimension includes impacts on researchers; and (5) social participation includes impacts on external actors such as civil society, and private and public sectors.

\subsubsection{Promotion of university entrepreneurship as USR catalysts}

Entrepreneurship is an important catalyst to social development, particularly, when the economy is focused on a more technological society (Schumpeter \& Opie 1934). Universities are a key factor of technological and economic development (Mowery et al. 2001; Rosenberga \& Nelsonb 1994).

Thus, since entrepreneurship is considered an opportunity for the development of society (Stefanescu et al. 2011), it is considered that 
entrepreneurship offers innovative solutions to social problems (OECD 2010). Sustainable entrepreneurship is viewed as a type of entrepreneurship that searches for environmental solutions (Dean \& McMullen 2007; Cohen \& Winn 2007; York \& Venkataraman 2010) and social challenges (Zahra et al. 2009).

Because the benefits of entrepreneurship are closely related to social and economic development, the issue deserves special attention to highlight the relationships between university and entrepreneurship. Firstly, it is important to point out that universities increase efforts to promote entrepreneurial projects (Rothaermel et al. 2007), due to the ability of universities to start and encourage the venture-creation process (Rasmussen \& Borch 2010). Moreover, universities boost entrepreneurship activities in order to achieve social benefits (Williams et al. 2016). Universities take care of their social responsibilities, particularly to student demands, as educational impacts seem to be the university area with the highest level of attention (Vázquez et al. 2016), and students seem to represent the main stakeholder (Sánchez \& Mainardes 2016).

\subsection{Hypotheses}

The knowledge economy (Drucker 1969) has given the universities new economic and social challenges, inducing them to redefine their objectives, strategies and policies (GUNI 2017; Benavides 2001). These challenges need to incorporate strategic initiatives in their strategic plans (Keller 1983) because such plans are an instrument that comprises university mission, vision, strategic objectives, and performance indicators (Llinàs et al. 2011).

Therefore, this work suggests as hypotheses that a series of USR catalysts are considered in strategic plans to address these economic and social challenges:

- H1. Universities include in their strategic plans the following catalysts to achieve responsible university management:

$\bigcirc$ Responsible economic management of resources

- Equal opportunities

- Promotion of environmental care

- Responsible management staff

- H2. Universities include in their strategic plans the following catalysts to achieve responsible academic training:

○ Development of responsible capabilities and competences among students

○ Efforts to student employability

- Adjust academic training to society needs

- H3 Universities include in their strategic plans the following catalysts to achieve responsible research:

- Ethical ways to investigate and to produce useful research to society

- H4 Universities include on their strategic plans the following catalysts to achieve responsible social development:

$\circ$ Promotion of solidarity and university cooperation

\section{METHOD}

To develop this work, a thematic analysis was driven by a deductive a priori template of codes (Crabtree \& Miller 1999). In this research, the template was defined by a previous research obtained using a Delphi method as explained previously. 
To develop a deductive analysis, the template, or codebook as Crabtree \& Miller (1999) called it, is defined before the in-depth analysis of the data. In this case, a model of USR obtained from the Delphi method was taken as a template to develop this research. Thus, the thematic analysis driven in this work is explained in six phases (see Table 3).

The total of universities with open access in their strategic plans was 41 . However, only 23 were up-to-date, as Section 3.1 explains. Consequently, 23 strategic plans were entered into ATLAS.ti, a computer program that is widely used in qualitative data analysis and data coding processes. The objective of this document collection was to gather strategic plans to analyse and represent USR catalysts considered within strategic plans.

\subsection{Sample}

The sample has been built considering 76 Spanish universities (CRUE 2017) and following the process presented in Figure 1. Firstly, 41 strategic plans with open access were identified, and the 35 universities without an available strategic plan were contacted via e-mail. Nevertheless, those who answered the request did not have the strategic plans updated to 2017. In consequence, the sample consists of 23 valid strategic plans (see Table 4).

\subsection{Instrument}

As an instrument of analysis, the ATLAS.ti program was chosen because it enables developing a systematic analysis and has capacity for a large amount of data. Moreover, the program provides tools to codify and annotate special findings to facilitate analysis of results.

\subsection{Validation}

The validation of this study has been divided into two parts:

1. Validation of the original model obtained from the study 'Drivers and barriers of university social responsibility: integration into strategic plans' in which the reliability of the internal consistency of the questionnaire applied to academic authorities was tested. It was shown that questions of the instrument measured the same construct and were highly correlated.

2. Validation of thematic analysis, in this part, validation and credibility is related to corroborating and legitimating coded themes, which is the process of confirming the findings (Crabtree \& Miller 1999). In this line, the different researchers of this work made the corresponding verifications of results from multiple perspectives.

\section{ANALYSIS OF RESULTS}

The presentation of results is divided into three parts to reflect the three objectives of this work: 1) examine the main catalysts of university social responsibility (USR) and give response to the hypotheses; 2) represent relations among USR catalysts through semantic networks; and 3) analyse the role of university promotion of entrepreneurship.

\subsection{Main catalysts in strategic plans and hypotheses}

In this part, the main catalysts are presented for each dimension giving response to the four hypotheses. The catalysts were chosen by the number of 
mentions in strategic plans, showing those catalysts that appear on more than $50 \%$ of the plans.

\subsubsection{Results for responsible university management}

The main catalysts for the management dimension (Table 5) show that 16 of the 23 universities plan to respond to training demands of their staff. Moreover, it can be observed that the catalyst 'equal opportunities' does not have sub-catalysts. Nevertheless, more than $50 \%$ of strategic plans mention 'equal opportunities'. Considering that the four catalysts are specified, H1 (see Section 2.2) is accepted.

\subsubsection{Results on responsible research}

The main catalysts of USR in research (Table 7) seems to be the research dissemination with $56 \%$ indicating strategic plans. Because 'ethical way to investigate and interpret findings' appears on more than $50 \%$ of the plans, H3 (see Section 2.2) is accepted.

\subsubsection{Results on responsible social development}

The main catalysts for social development (Table 8) are more related to university communications to society than an effort in university cooperation. As $56 \%$ of universities mention this point, $\mathrm{H} 4$ (see Section 2.2) is accepted.

\subsubsection{Results on responsible academic training}

The efforts to achieve USR for the academic training dimension (Table 6) seem to be inclined to the promotion of foreign languages, mainly English, as a manner to adjust training to meet the needs of society. It is also observed that promotion by universities of entrepreneurial projects is used as an effort to increase student employability. As more than 50\% universities include the three catalysts H2 (see Section 2.2) is accepted.

\subsection{Relation among USR catalysts through semantic networks}

In this part, relationships among catalysts and sub-catalysts are presented by means of four semantic networks, indicating the dimensions of university work.

Semantic networks were developed to identify how catalysts involve other sub-catalysts in the strategic plans and show how these concepts are linked. The analysis and design of networks were developed using the ATLAS.ti program.

To build semantic networks, each catalyst found in the 23 strategic plans was separated into the four university dimensions. Relationships among catalysts were then detected in the text during an analysis of the content. In this part, it can be observed that some catalysts include sub-catalysts. For instance, if plans specify actions such as 'energy efficiency plan', this sub-catalyst was included in the subcatalyst 'responsible resource management' which is included in the catalyst 'promotion of environmental care'.

The semantic network considering dimension of responsible university management (see Figure 2) shows an extensive network of sub-catalysts. It is observed that the sub-catalyst linked to 'promotion of environmental care' is aligned with statements of GRI and PRME (GRI 2017; PRME 2018). The semantic network according to the dimension of responsible academic training (see Figure 3) shows the relations for catalysts and sub-catalysts in strategic plans, representing the specific actions for each catalyst. The semantic network that considers the dimension of responsible research (see Figure 4) shows the different 
actions related to ethical manners to investigate and the actions to disseminate research. Finally, the semantic network related to the dimension of responsible social development (see Figure 5) shows all the sub-catalysts related to the promotion of university solidarity and cooperation.

\subsection{Entrepreneurship as USR catalysts}

Results have shown that $100 \%$ of the sample (see Table 9) implements entrepreneurial actions as catalysts to achieve USR. Universities look for responsible academic training, and entrepreneurship projects encourage students to develop their own business and give training in the process. Responsible social development is also pursued since entrepreneurship has been considered as an opportunity for society to develop (Stefanescu et al. 2011). It can be observed that six of the universities include in their websites a program called YUZZ (Explorer 2016) as external entrepreneurial support for training, economic support, and business advice.

\section{CONCLUSIONS}

To improve university performance it is necessary to identify specific activities to measure catalysts. University social responsibility is taken as a strategic decision from academic authorities as expressed in their strategic plans. Thus, a study was carried out to achieve three main objectives: (1) examine the main catalysts of university social responsibility and respond to the hypotheses;

(2) symbolise through semantic networks the relations among USR catalysts; and (3) analyse the role of universities in the promotion of entrepreneurship.

To develop this work, a thematic analysis was driven by a deductive a priori template of codes, selecting a sample of 23 up-to-date strategic plans, which were entered in the ATLAS.ti. computer program.

Results show university efforts to search for a stable economic funding, mainly through private funds. Moreover, a wide specification of actions to achieve catalysts is suggested, as is the case of the 'equal opportunities' catalysts. The results also highlight the university's efforts to adapt academic training to society's needs, specially through the teaching of English. Moreover, it is observed that only 13 strategic plans specify the promotion of entrepreneurial projects, and this finding disagrees with the results of searching each website, in which $100 \%$ of the sample made efforts in entrepreneurship. Furthermore, responsible research disseminates research without a specification of how to do it (publications, seminars, conferences, etc.). However, strategic plans mention the 'search of economic source' and 'attraction of research talent' to achieve the dissemination of research. The dimension of responsible social development is more related to the promotion of university communications with society. The other sub-catalysts, such as 'fight discrimination' do not specify the actions taken. As every dimension (on a different grade) has fulfilled the proposed catalyst the four hypotheses were accepted.

In addition, the relationship between university social responsibility and entrepreneurship is presented as an opportunity to increase university efforts regarding student employability and social development, and to give innovative solutions to social issues. Universities are aware of these benefits because all of the sample have implemented projects or specific programmes to promote entrepreneurship. This can be explained considering the student as the main university stakeholder, since the university focuses on designing and 
implementing strategic initiatives to meet student demands and increase the employability of students.

Although this analysis was carefully developed, there are several USR catalysts that were not listed in the model. Strategic plans frequently do not give extensive explanations of how to develop catalysts, and so make them too general. An interesting future research could be done with the support of the Global Reporting Initiative, and the international ISO 2600 standard.

\section{Acknowledgments}

This work has been supported by federal financing from the National Council of Science and Technology (CONACYT) of Mexico. This work has been possible with the collaboration of academic authorities who with their knowledge and experience are helping to build and improve the model of drivers of university social responsibility.

\section{References}

Albon, S.P., Iqbal, I. \& Pearson, M.L., 2016. Strategic Planning in an Educational Development Centre: Motivation, Management, and Messiness. , p.20.

Aleong, C., 2007. An empirical and qualitative study of the strategic planning process of a higher education institution. Journal of College Teaching and Learning, 4(4), pp.33-44.

Araya, D. \& Peters, M.A., 2010. Education in the creative economy: knowledge and learning in the age of innovation, New York: Peter Lang.

Benavides, V., 2001. Bases para la elaboración del Plan Estratégico de la Universidad de Málaga. Cuadernos IRC, (8).

Bowen, H., 1953. Social responsibilities of the businessman. Harper \& Brothers, New York, Estados Unidos.

Boyatzis, R., 1998. Transforming qualitative information: Thematic analysis and code development, Thousand Oaks, CA: SAGE Publications, Inc.

Braun, V. \& Clarke, V., 2006. Using thematic analysis in psychology. Qualitative Research in Psychology, 3(2), pp.77-101.

Burke, L. \& Logsdon, J., 1996. How Corporate Social Responsibility Pays Off. Long Range Planning, 29(4), pp.495-502.

Burrows, J., 1999. Going beyond labels: A framework for profiling institutional stakeholders. Contemporary Education, 70(4), pp.5-10.

Cambridge Dictionary, 2017. Cambridge Business English Dictionary. Cambridge University Press, p.http://dictionary.cambridge.org/es/diccionario/ing.

Candy, V. \& Gordon, J., 2011. The Historical Development Of Strategic Planning Theories. International Journal of Management \& Information Systems, 15(4), pp.71-90.

Cohen, B. \& Winn, M.I., 2007. Market imperfections, opportunity and sustainable entrepreneurship. Journal of Business Venturing, 22(1), pp.29-49.

Cooke, P., 2007. Regional innovation, entrepreneurship and talent systems. Int. J. Entrepreneurship and Innovation Management, 7(2/3/4/5), pp.117-139.

Cowburn, S., 2005. Strategic planning in higher education: Factor fiction? Perspectives, 9(4), pp.103-109.

Crabtree, B. \& Miller, W., 1999. A template approach to text analysis: Developing and using codebooks. In B. Crabtree \& W. Miller, eds. Doing qualitative research. Newbury Park, CA: SAGE Publications, Inc., pp. 163-177.

Cronje, 2015. The effects of volunteering on student volunteers. Progressio: South 
African Journal for Open and Distance Learning Practice, 37(2), pp.1-20.

CRUE, 2017. Conferencia de Rectores de las Universidades Españolas. CRUE Universidades Españolas, p.http://www.crue.org/SitePages/QueEsCrueUniversidad.

Dean, T.J. \& McMullen, J.S., 2007. Toward a theory of sustainable entrepreneurship: Reducing environmental degradation through entrepreneurial action. Journal of business venturing, 22(1), pp.50-76.

Drucker, P.F., 1969. The Age of Discontinuity 1st Edition Guidelines to Our Changing Society, Butterworth-Heinemann.

Dumay, J.C., Guthrie, J. \& Farneti, F., 2010. GRI Sustainability Reporting Guidelines for Public and Third Sector Organizations. Public Management Review, 12(4), pp.531-548.

Explorer, 2016. Explorer powered by Santander. Available at: http://yuzz.org.es/que-esexplorer/ [Accessed December 7, 2017].

Ferreira, J., Fernandes, C. \& Ratten, V., 2017. The Influence of Entrepreneurship Education on Entrepreneurial Intentions. In Entrepreneurial Universities Exploring the Academic and Innovative Dimensions of Entrepreneurship in Higher Education. Springer International Publishing.

García, M. \& Suárez, M., 2013. El método Delphi para la consulta a expertos en la investigación científica. Revista Cubana de Salud Pública, 39(2), pp.253-267.

Garriga, E. \& Melé, D., 2004. Corporate social responsibility theories: mapping the territory. Journal of business ethics, 53, pp.51-71.

Gibbs, G. \& Coffey, M., 2016. The Impact Of Training Of University Teachers on their Teaching Skills, their Approach to Teaching and the Approach to Learning of their Students. Active Learning in Higher Education, 5(1), pp.87-100.

GRI, 2017. Global Reporting Initiative., p.https://www.globalreporting.org/information/about-.

GUNI, 2017. Higher Education in the World 6. Towards a Socially Responsible University: Balancing the Global with the Local, Girona: United Nations Educational Scientific and Cultural Education (UNESDOC).

Heracleous, L., 1998. Linking Strategic Thinking with Strategic Planning. Long Range Planning, 31(3), pp.481-487.

Hines, J., Hungerford, H. \& Tomera, A., 1987. Analysis and synthesis of research on responsible environmental behaviour: a meta-analysis. Journal of environmental Education, 18(2).

Hockerts, K. \& Wüstenhagen, R., 2010. Greening Goliaths versus emerging DavidsTheorizing about the role of incumbents and new entrants in sustainable entrepreneurship. Journal of business venturing, 25(5), pp.481-492.

Hrebiniak, L.G., 2007. Making strategy work Whartoon S., New Jersey: Pearson Education, Inc.

ISO 26000, 2017. ISO 26000 Social Responsibility. International Organization for Standarization, p.https://www.iso.org/iso-26000-social-responsibilit.

Jacobs, J.A., 1996. Gender Inequality and Higher Education. Annual Review of Sociology, 22, pp.153-185.

Jongbloed, B., Jurgen, E. \& Salerno, C., 2008. Higher education and its communities: Interconnections, interdependencies and a research agenda. High Educ, 56, pp.303-324.

Keller, G., 1983. Academic Strategy: The management revolution in American higher education. The John Hopkins University Press. Baltimore.

Kvint, V., 2009. The Global Emerging Market: Strategic Management and Economics, 
Taylor \& Francis.

De la Cruz, C. \& Sasia, P., 2008. La responsabilidad de la universidad en el proyecto de construcción de una sociedad. Revista Educación Superior y Sociedad, 13(2), pp.17-52. Available at: http://unesdoc.unesco.org/images/0018/001820/182067s.pdf.

Larrán Jorge, M. \& Andrades Peña, F.J., 2015. Análisis de la responsabilidad social universitaria desde diferentes enfoques teóricos. Revista Iberoamericana de Educación Superior, 6(15), pp.91-107.

Lin, T.C.L., 2013. The Corporate Governance of Iconic Executives. Notre Dame Law Review, 87(1), p.351.

Linstone, H. \& Turoff, M., 1975. The Delphi Method: Techniques and Applications. Addison-Wesley, Reading, MA.

Llinàs, X., Girotto, M. \& Solé, F., 2011. University strategic management and the efficacy of the managerial tools: The case of the Spanish universities [La dirección estratégica universitaria y la eficacia de las herramientas de gestión: El caso de las universidades españolas]. Revista de Educacion, 355, pp.33-54. Available at: http://www.scopus.com/inward/record.url?eid=2-s2.080052570584\&partnerID=40\&md5=591657b273645697946145c203eeea37.

Marginson, S., 2007. University mission and identity for a post post-public era. Higher Education Research \& Development, 26(1), pp.117-131.

McWilliams, A. \& Siegel, D., 2001. Corporate social responsibility: A theory of the firm perspective. Academy of Management Review, 26(1), pp.117-127.

Mintzberg, H., 2009. Managing, San Francisco: Berrett-Koehler.

Mintzberg, H., 1994. The Fall and Rise of Strategic Planning,

Mintzberg, H. \& Quinn, J.B., 1996. The Strategy Process: Concepts, Contexts, Cases, London: Prentice-Hall International.

Mitchell, R. K., Agle, B. R., \& Wood, D.J., 1997. Toward a theory of stakeholder identification and salience: Defining the principle of who and what really counts, Netherlands.

Morris, M.H. et al., 2011. Inner city engagement and the university: Mutuality, emergence and transformation. Entrepreneurship \& Regional Development: An International Journal, 23(5-6), pp.287-315.

Mowery, D. et al., 2001. The growth of patenting and licensing by U.S. universities: an assessment of the effects of the Bayh-Dole Act of 1980. Research Policy, 30(1), pp.99-119.

Murray, C. \& Lombardi, C., 2010. The Effects of Disability-Focused Training on the Attitudes and Perceptions of University Staff. Remedial and Special Education, 32(4), pp.290-300.

Nag, R., Hambrick, D.C. \& Chen, M.-J., 2007. What is strategic management, really? Inductive derivation of a consensus definition of the field. Strategic Management Journal, 28(9), pp.935-955.

OECD, 2010. SMEs, Entrepreneurship and Innovation, Series: OECD Studies on SMEs and Entrepreneurship. In Schaltegger, S., 2000. Vom Bionier zum Sustainopreneur. Rio.

Owen, R., Macnaghten, P. \& Stilgoe, J., 2012. Responsible research and innovation: From science in society to science for society, with society. Science and Public Policy, 39(6), pp.751-760.

Porter, M.E., 1980. Competitive strategy: Techniques for analyzing industries and competitors, New York: Free Press.

Porter, M.E., 1996. What is a Strategy? Harvard Business Review. 
PRME, 2018. PRME six principles. United Nations Global Compact, p.http://www.unprme.org/about-prme/the-six-principle.

Ramos-Monge, E.L., Llinàs-Audet, X. \& Barrena-Martínez, J., 2017a. 'Drivers and barriers of University Social Responsibility: integration into strategic plans'. World Review of Entrepreneurship, Management and Sustainable Development, IN PROCESS.

Ramos-Monge, E.L., Llinàs-Audet, X. \& Barrena-Martínez, J., 2017b. Universities as Corporate Entities: The Role of Social Responsibility in Their Strategic Management. In Corporate Governance and Strategic Decision Making. Rijeka, Croatia: INTECH, pp. 199-215.

Rasche, A., Morsing, M. \& Moon, J., 2017. Corporate Social Responsibility: Strategy, Communication, Governance Cambridge., Cambridge.

Rasmussen, E. \& Borch, O.J., 2010. University capabilities in facilitating entrepreneurship: A longitudinal study of spin-off ventures at mid-range universities. Research Policy, 39, pp.602-612.

Ratten, V., 2017. Entrepreneurial universities: the role of communities, people and places. Journal of Enterprising Communities: People and Places in the Global Economy, 11(3), pp.310-315.

Ratten, V., Ramadani, V. \& Fayolle, A., 2017. Exploring family farms and sustainability entrepreneurship in Australian farmers' markets. In F. Warwick \& J. Laing, eds. Exhibitions, Trade Fairs and Industrial Events. Taylor \& Francis, p. 230.

Ratten, V. \& Suseno, S., 2006. Knowledge development, social capital and alliance learning. International Journal of Educational Management, 20(1), pp.60-72.

Ratten, V. \& Welpe, I., 2011. Special issue: Community-based, social and societal entrepreneurship, Entrepreneurship \& Regional Development. Entrepreneurship \& Regional Development, 23(5-6), pp.283-286.

Reavill, L., 1998. Quality assessment, total quality management and the stakeholders in the UK higher education system. Managing Service Quality: An International Journal, 8(1), pp.55-63.

Rexhepia, G., Bexhetic, S. \& Kurtishib, G., 2013. Corporate Social Responsibility (CSR) and Innovation The drivers of business growth? Procedia - Social and Behavioral Sciences, 75(3), pp.532-541.

Rice, M.P., Fetters, M.L. \& Greene, P.G., 2014. University-based entrepreneurship ecosystems: a global study of six educational institutions. Int. J. Entrepreneurship and Innovation Management, 18(5/6), pp.481-501.

Rice, P. \& Ezzy, D., 1999. Qualitative research methods: A health focus, Melbourne: Oxford University Press.

Rosenberga, N. \& Nelsonb, R.R., 1994. American universities and technical advance in industry. Research Policy, 23(3), pp.323-348.

Rothaermel, F., Agung, S. \& Jiang, L., 2007. University entrepreneurship: a taxonomy of the literature. Industrial and Corporate Change, 16(4), pp.691-791.

Rueda, G. \& Uribe, M., 2011. Aportes de la información contable a una responsabilidad empresarial acorde con las necesidades de la sociedad. Una mirada crítica. Cuadernos de Administración, 24(43), pp.241-260.

Sánchez, I. \& Mainardes, E., 2016. University social responsibility: a student base analysis in Brazil. International Review on Public and Nonprofit Marketing, 13(2), pp.151-169. Available at: http://dx.doi.org/10.1007/s12208-016-0158-7.

Schumpeter, J.A. \& Opie, R., 1934. The theory of economic development: An inquiry into profits, capital, credit, interest, and the business cycle, Cambridge: Mass: 
Harvard University Press.

Shah, C., 2013. Effects of awareness on coordination in collaborative information seeking. J Am Soc Inf Sci Tec, 64(6), pp.1122-1143.

Shailer, G., 2004. An Introduction to Corporate Governance in Australia, Australia, Sydney: Pearson Education.

Stefanescu, D., Gabor, M.R. \& Contiu, L.C., 2011. International Conference on Economy and Management Transformation. In Changes of the European Countries distributions based on Entrepreneurship and Social Economic Sustainable Development Indicators, in Recent Researchers in Economics and Management Transformation. pp. 153-158.

Teelken, C. \& Deem, R., 2013. All are equal, but some are more equal than others: managerialism and gender equality in higher education in comparative perspective. Comparative Education, 49(4), pp.520-535.

UNED | Universidad Nacional de Educación a Distancia, La UNED emprende. Available at: http://portal.uned.es/portal/page?_pageid=93,644264\&_dad=portal\&_schema=PO RTAL\&id_noticia=1529 [Accessed December 6, 2017].

UNESCO, 1998. Declaración Mundial sobre la Educación Superior en el Siglo XXI: Visión y Acción. In Conferencia Mundial Sobre la Educación Superior. UNESCO. París, Francia.

UNIBILITY, U.M.S.R., 2017. Guidelines for Universities Engaging in Social Responsibility,

Universidad de Alcalá, Escuela de Emprendimiento. Available at: https://escuelaemprendimiento.uah.es/EmprendimientoIndex [Accessed December $1,2017]$.

Universidad de Alicante, 2017. Proyecto ua:emprende. Available at: https://uaemprende.ua.es/ [Accessed December 2, 2017].

Universidad de Cádiz, Cátedra de Emprendedores. Available at: http://emprendedores.uca.es/proyectos/ [Accessed December 9, 2017].

Universidad de Cantabria, Vicerrectorado de Estudiantes y Emprendimiento. Available at: https://web.unican.es/consejodireccion/vcestudiantesempleabilidadyemprendimiento/area-de-emprendimiento [Accessed December 5, 2017].

Universidad de Deusto, 2017. ENTREPRENEURSHIP. Available at: http://www.deusto.es/cs/Satellite/deusto/en/entrepreneurship-1?cambioidioma=si [Accessed December 4, 2017].

Universidad de Extremadura, Emprendimiento. Available at: https://www.unex.es/organizacion/gobierno/vicerrectorados/vicealumn/funciones/e mprendimiento [Accessed December 7, 2017].

Universidad de Jaén, Programa de Apoyo a Emprendedores. Available at: https://www10.ujaen.es/conocenos/organos-gobierno/vicest/programa-de-apoyoemprendedores [Accessed December 6, 2017].

Universidad de la Rioja, Cátedra de Emprendedores. Available at: https://fundacion.unirioja.es/Catedras_subsecciones/view/6/Catedra-deEmprendedores [Accessed December 5, 2017].

Universidad de Las Palmas de Gran Canaria, 2016. Cátedra Fundación DISA-ULPGC. Available at: http://www.catedrafundaciondisaulpgc.org/ [Accessed December 7, 2017].

Universidad de Salamanca, 2017. Vicerrectorado de Investigación y Transferencia. Available at: https://emprende.usal.es/ [Accessed December 6, 2017]. 
Universidad del Pais Vasco, Emprendimiento. Available at: https://www.ehu.eus/es/web/gipuzkoa/emprendizaje [Accessed December 6, 2017].

Universidad Loyola Andalucía, EMPLEABILIDAD Y EMPRENDIMIENTO. Available at: https://www.uloyola.es/servicios/empleabilidad-yemprendimiento/emprendimiento [Accessed December 3, 2017].

Universidad Pontificia de Comillas, Programa de Apoyo a Emprendedores. Available at:

http://www.comillas.edu/es/?option=com_content\&view=article\&id=303\&Itemid= 641\&jjj=1512577301696 [Accessed December 4, 2017].

Universidad San Jorge, 2016. APOYO Y FOMENTO DE EMPRENDEDORES.

Available at: https://www.usj.es/alumnos/orientacion-empleo/emprender

[Accessed December 5, 2017].

Universidade da Coruña, Creación de Empresas. Available at: http://otri.udc.es/creacion-de-empresas/ [Accessed December 6, 2017].

Universidade de Santiago de Compostela, Área de Valorización, Transferencia e Emprendemento. Available at: http://www.usc.es/es/investigacion/avte/ [Accessed December 6, 2017].

Universitat de Barcelona, Barcelona Institut d'Emprenedoria. Available at: http://www.ub.edu/emprenedoria/ [Accessed December 6, 2017].

Universitat de les Illes Balears, 2017. Programa de creación de empresas. Available at: http://innovacio.uib.es/es/Foment-de-lesperit-emprenedor/ [Accessed November 29, 2017].

Universitat de València, 2017. Investigación y Transferencia. Available at: https://www.uv.es/uvweb/universidad/es/investigaciontransferencia/emprendeduria/presentacion-novedades-1285946448373.html [Accessed December 6, 2017].

Universitat Oberta de Catalunya, Emprendimiento. Available at: http://alumni.uoc.edu/opencms_alumni/opencms/es/servicios/emprendimiento/inde x.html [Accessed December 1, 2017].

Universitat Politècnica de València, 2012. Vicerrectorado de Empleo y Emprendimiento. Available at: https://www.upv.es/entidades/VE2/index-es.html [Accessed December 6, 2017].

Universitat Pompeu Fabra, Universitat Pompeu Fabra. Available at: https://www.upf.edu/web/innovacio/emprenedors-estudiants [Accessed December $6,2017]$.

USDG, 2017. USDG Universities Susteinable Development Goals. Putting the 2030 Agenda at the heart of our universities' work, p.http://ods.cat/en/.

Vallaeys, F., 2013. La Responsabilidad Social Universitaria: ¿Cómo entenderla para quererla y practicarla? Revista servicio comunitario, 2(1).

Vallaeys, F., De la Cruz, C. \& Sasia, P., 2009. Responsabilidad Social Universitaria. Manual primeros pasos, México D.F., México.: McGraw Hill.

Vázquez, J.L., Aza, C. \& Lanero, A., 2016. Citizens' perceptions on social responsibility in public administration organizations: a case study on Spain. Transylvanian Review of Administrative Sciences, (48), pp.166-183.

Williams, C.C., Martinez-Perez, A. \& Kedir, A.M., 2016. Informal Entrepreneurship in Developing Economies: The Impacts of Starting Up Unregistered on Firm Performance. Entrepreneurship Theory and Practice.

York, J.G. \& Venkataraman, S., 2010. The entrepreneur-environment nexus: Uncertainty, innovation, and allocation. Journal of Business Venturing, 25(5), 
pp.449-463.

Zahra, S.A. et al., 2009. A typology of social entrepreneurs: Motives, search processes and ethical challenges. Journal of Business Venturing, 24(5), pp.519-532. 


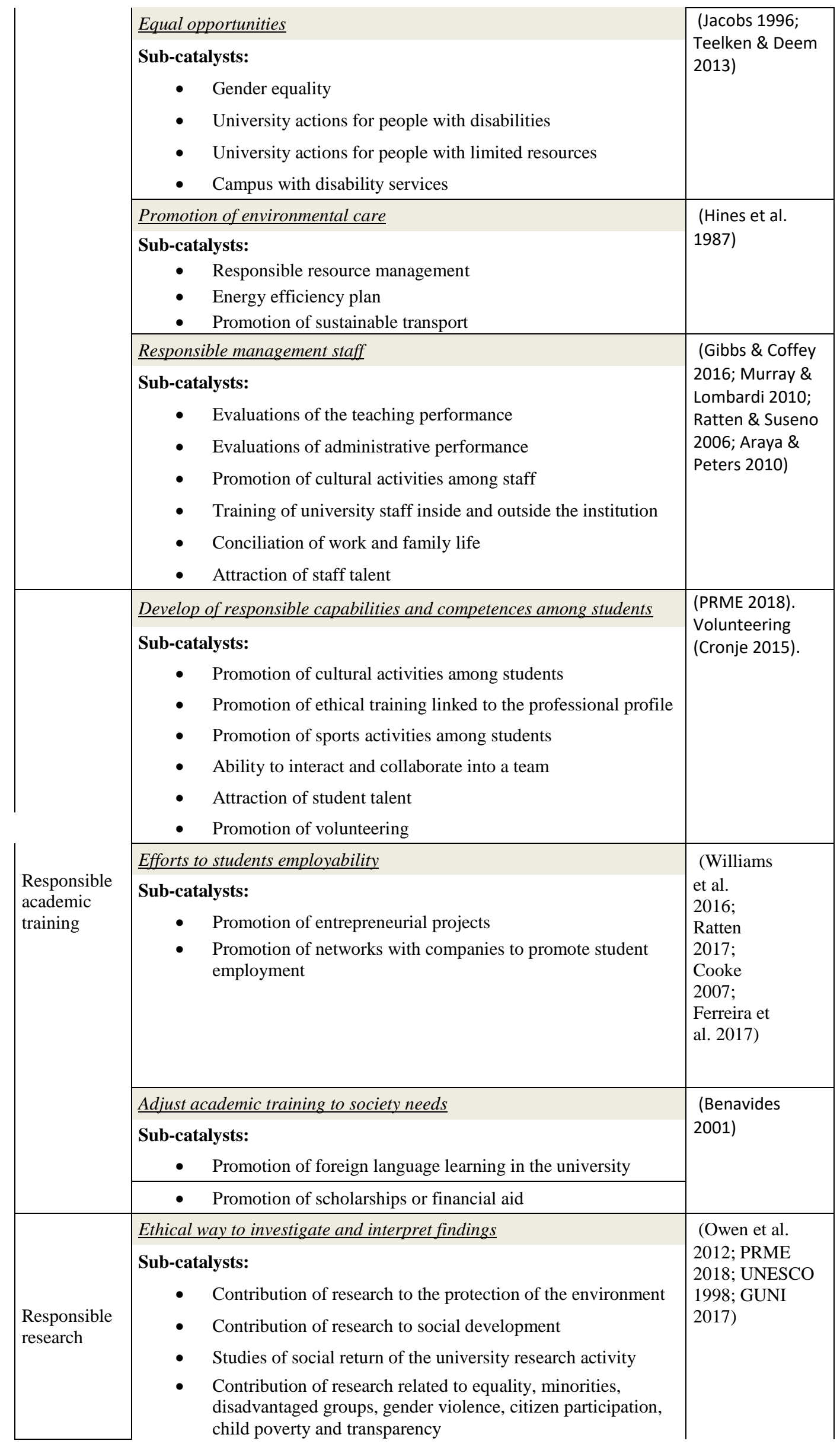




\begin{tabular}{|c|c|c|}
\hline & $\begin{array}{l}\text { University participation in the definition of national research } \\
\text { priorities } \\
\text { - University actions to disseminate research (publications, } \\
\text { seminars, conferences, etc.) } \\
\text { - Attraction of research talent } \\
\text { - Look for private funds for research } \\
\text { - Look for public funds for research } \\
\text { Fostering research relationships with companies or others } \\
\text { organizations }\end{array}$ & \\
\hline $\begin{array}{l}\text { Responsible } \\
\text { social } \\
\text { development }\end{array}$ & $\begin{array}{l}\text { Promotion of solidarity and university cooperation } \\
\text { Sub-catalysts: } \\
\text { - Fight discrimination } \\
\text { - Promotion of cultural and sporting activities to society } \\
\text { - Attention to current problems of politics, economy, health, } \\
\text { etc. } \\
\text { - Promotion of university communication through different } \\
\text { paths (social networks, meetings, web pages, conferences, } \\
\text { - } \text { Dengresses, etc.) } \\
\text { - Promolop University Social Responsibility memory } \\
\text { - Promotion of entrepreneurial projects involving the } \\
\text { participation of society }\end{array}$ & $\begin{array}{l}\text { (GUNI 2017; De } \\
\text { la Cruz \& Sasia } \\
\text { 2008; UNESCO } \\
\text { 1998; Morris et } \\
\text { al. 2011; } \\
\text { Rexhepia et al. } \\
\text { 2013) }\end{array}$ \\
\hline
\end{tabular}

Table 2.Model and literature support of catalysts and sub-catalysts of USR

\begin{tabular}{|c|c|c|}
\hline Phase & Description of phase & Contribution \\
\hline 1 & Developing the code manual & $\begin{array}{l}\text { In this stage, a depth analysis of USR theory was carried out, } \\
\text { theoretical concepts was taken to coding interesting features of } \\
\text { the data related to catalysts to USR. Five code categories were } \\
\text { integrated into code manual (dimensions of university work). }\end{array}$ \\
\hline 2 & Testing the reliability of codes & $\begin{array}{l}\text { To determinate the applicability of the raw information coding a } \\
\text { Delphi method was carried out to test the code manual. Thus, } \\
\text { the Delphi method consulted } 27 \text { academic experts on social } \\
\text { responsibility from Spain and Mexico. Alpha of Cronbach to } \\
\text { validate internal consistency of the questionnaire was measured } \\
\text { obtaining satisfactory results. }\end{array}$ \\
\hline 3 & $\begin{array}{l}\text { Summarizing data and identifying } \\
\text { initial themes }\end{array}$ & $\begin{array}{l}\text { Reading raw data from the strategic plans. Then, recognizing } \\
\text { key points of whole analysis. In this step, strategic actions } \\
\text { specified into plans were analysed. }\end{array}$ \\
\hline 4 & $\begin{array}{l}\text { Applying template of codes and } \\
\text { additional coding }\end{array}$ & $\begin{array}{l}\text { To use a "template analytic technique". A model resulting from } \\
\text { the Delphi method was introduced into ATLAS.ti program. This } \\
\text { model include a series of USR catalysts into HEI, all those } \\
\text { catalysts were consensual by experts. Thus, coding the segments } \\
\text { of data in plans took part in the process, matching related } \\
\text { segments with codes (USR catalysts). Also, inductive codes } \\
\text { (Boyatzis 1998)were added, due to the fact that they were } \\
\text { closely related with other catalysts that were already registered } \\
\text { on USR drivers model. Ones the plans were coded, semantic } \\
\text { network were developed to cluster the codes for each area of } \\
\text { university work. }\end{array}$ \\
\hline 5 & $\begin{array}{l}\text { Connecting the codes and } \\
\text { identifying themes }\end{array}$ & $\begin{array}{l}\text { This connection of codes is the process of determining patterns } \\
\text { (Crabtree \& Miller 1999). The themes were redefined. In this } \\
\text { work, themes are equivalent to dimensions of university work. } \\
\text { Although these dimensions were pre-defined, catalysts were } \\
\text { grouped into catalysts (general) and sub-catalysts (more specific } \\
\text { catalysts). }\end{array}$ \\
\hline 6 & $\begin{array}{l}\text { Corroborating and legitimating } \\
\text { coded themes }\end{array}$ & $\begin{array}{l}\text { Corroborating it to confirm the findings (Crabtree \& Miller } \\
\text { 1999). This phase is closely related to validity and credibility. In } \\
\text { this study, researchers of this work had made the verifications of }\end{array}$ \\
\hline
\end{tabular}


results. Making verification possible as researches gave their perspectives to validate results.

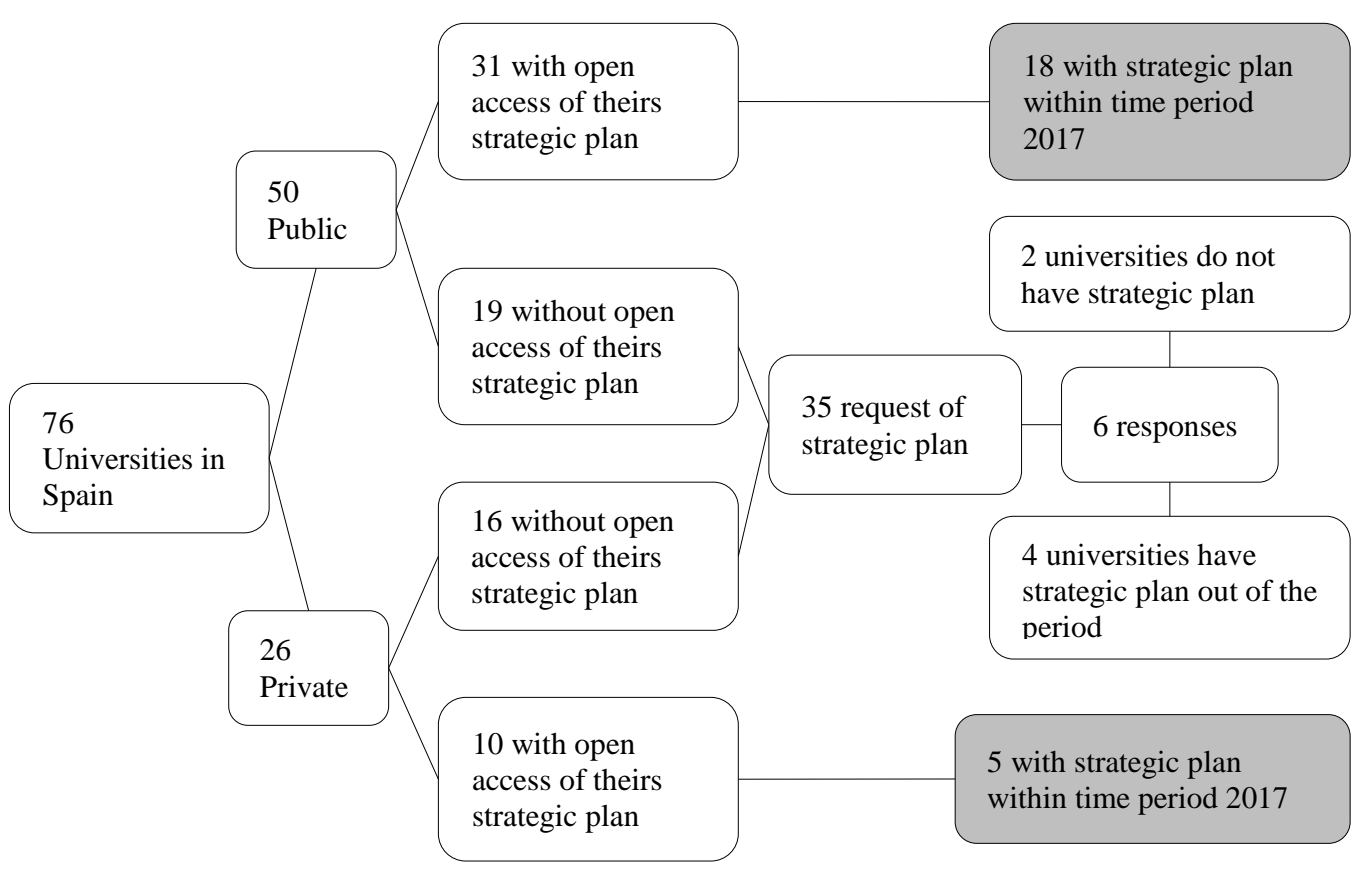

Figure1.Process of the sample selection. 


\begin{tabular}{ll} 
Spanish University plans as the sample & $\begin{array}{l}\text { Duration of } \\
\text { university plan }\end{array}$ \\
\hline Universitat de València & $2016-2019$ \\
\hline Universitat Politècnica de València & $2015-2020$ \\
\hline Universidade de Santiago de Compostela & $2011-2020$ \\
\hline Universitat Pompeu Fabra & $2016-2025$ \\
\hline Universidade da Coruña & $2013-2020$ \\
\hline Universidad de Jaén & $2014-2020$ \\
\hline Universidad Pontificia de Comillas & $2014-2018$ \\
\hline Universitat de Barcelona & $2008-2020$ \\
\hline Universidad de Salamanca & $2013-2018$ \\
\hline Universidad del Pais Vasco & $2012-2017$ \\
\hline Universitat Oberta de Catalunya & $2014-2020$ \\
\hline Universidad San Jorge & $2015-2020$ \\
\hline Universitat de les Illes Balears & $2015-2017$ \\
\hline Universidad Loyola Andalucía & $2013-2018$ \\
\hline UNED Universidad Nacional de Educación a Distancia & $2014-2017$ \\
\hline Universidad de Deusto & $2014-2018$ \\
\hline Universidad de Cádiz & $2015-2020$ \\
\hline Universidad de la Rioja & $2014-2020$ \\
\hline Universidad de Extremadura & $2014-2018$ \\
\hline Universidad de Las Palmas de Gran Canaria & $2015-2018$ \\
\hline Universidad de Alcalá & $2015-2017$ \\
\hline Universidad de Alicante & $2014-2019$ \\
\hline Universidad de Cantabria & $2015-2018$ \\
\hline
\end{tabular}

Table 4.Universities with strategic plan taking as sample

\begin{tabular}{|l|l|l|l|l|}
\hline $\begin{array}{l}\text { University } \\
\text { dimensions }\end{array}$ & Catalysts & Sub-Catalysts & $\begin{array}{l}\text { Strategic } \\
\text { plans } \\
\text { mentions }\end{array}$ & $\begin{array}{l}\text { Force in } \\
\text { percentage }\end{array}$ \\
\hline $\begin{array}{l}\text { Responsible } \\
\text { university } \\
\text { management }\end{array}$ & $\begin{array}{l}\text { Responsible economic } \\
\text { management of } \\
\text { resources }\end{array}$ & Look for stable funding sources & 13 & $56 \%$ \\
\cline { 2 - 5 } & Equal opportunities & Transparency and accountability & 12 & $52 \%$ \\
\cline { 2 - 5 } & $\begin{array}{l}\text { Promotion of } \\
\text { environmental care }\end{array}$ & $\begin{array}{l}\text { Responsible resource } \\
\text { management }\end{array}$ & 12 & $52 \%$ \\
\cline { 2 - 5 } & $\begin{array}{l}\text { Responsible management } \\
\text { staff }\end{array}$ & $\begin{array}{l}\text { Evaluations of the teaching } \\
\text { performance }\end{array}$ & 12 & $56 \%$ \\
\cline { 2 - 5 } & $\begin{array}{l}\text { Training of university staff } \\
\text { inside and outside the institution }\end{array}$ & 16 & $69 \%$ \\
\hline
\end{tabular}

Table 5.Main USR catalysts on university management

\begin{tabular}{|l|l|l|l|l|}
\hline $\begin{array}{l}\text { University } \\
\text { dimensions }\end{array}$ & Catalysts & Sub-Catalysts & $\begin{array}{l}\text { Strategic } \\
\text { plans } \\
\text { mentions }\end{array}$ & $\begin{array}{l}\text { Force in } \\
\text { percentage }\end{array}$ \\
\hline $\begin{array}{l}\text { Responsible } \\
\text { academic } \\
\text { training }\end{array}$ & $\begin{array}{l}\text { Develop of responsible } \\
\text { capabilities and } \\
\text { competences among } \\
\text { students }\end{array}$ & Promotion of volunteering & 12 & $52 \%$ \\
\cline { 2 - 5 } & $\begin{array}{l}\text { Efforts to students } \\
\text { employability }\end{array}$ & $\begin{array}{l}\text { Promotion of entrepreneurial } \\
\text { projects }\end{array}$ & 13 & $56 \%$ \\
\cline { 2 - 5 } & $\begin{array}{l}\text { Adjust academic training } \\
\text { to society needs }\end{array}$ & $\begin{array}{l}\text { Promotion of foreign language } \\
\text { learning in the university }\end{array}$ & 15 & $65 \%$ \\
\hline
\end{tabular}

Table 6.Main USR catalysts on academic training 


\begin{tabular}{|l|l|l|l|l|}
\hline $\begin{array}{l}\text { University } \\
\text { dimensions }\end{array}$ & Catalysts & Sub-Catalysts & $\begin{array}{l}\text { Strategic } \\
\text { plans } \\
\text { mentions }\end{array}$ & $\begin{array}{l}\text { Force in } \\
\text { percentage }\end{array}$ \\
\hline $\begin{array}{l}\text { Responsible } \\
\text { research }\end{array}$ & $\begin{array}{l}\text { Ethical way to } \\
\text { investigate and interpret } \\
\text { findings }\end{array}$ & $\begin{array}{l}\text { University actions to disseminate } \\
\text { research (publications, seminars, } \\
\text { conferences, etc.) }\end{array}$ & 13 & $56 \%$ \\
\hline
\end{tabular}

Table 7.Main USR catalysts on responsible research

\begin{tabular}{|l|l|l|l|l|}
\hline $\begin{array}{l}\text { University } \\
\text { dimensions }\end{array}$ & Catalysts & Sub-Catalysts & $\begin{array}{l}\text { Strategic } \\
\text { plans } \\
\text { mentions }\end{array}$ & $\begin{array}{l}\text { Force in } \\
\text { percentage }\end{array}$ \\
\hline $\begin{array}{l}\text { Responsible } \\
\text { social } \\
\text { development }\end{array}$ & $\begin{array}{l}\text { Promotion of solidarity } \\
\text { and university } \\
\text { cooperation }\end{array}$ & $\begin{array}{l}\text { Promotion of university } \\
\text { communication through different } \\
\text { paths (social networks, meetings, } \\
\text { web pages, conferences, } \\
\text { congresses, etc.) }\end{array}$ & 13 & $56 \%$ \\
\hline
\end{tabular}

Table 8.Main USR catalysts on social development

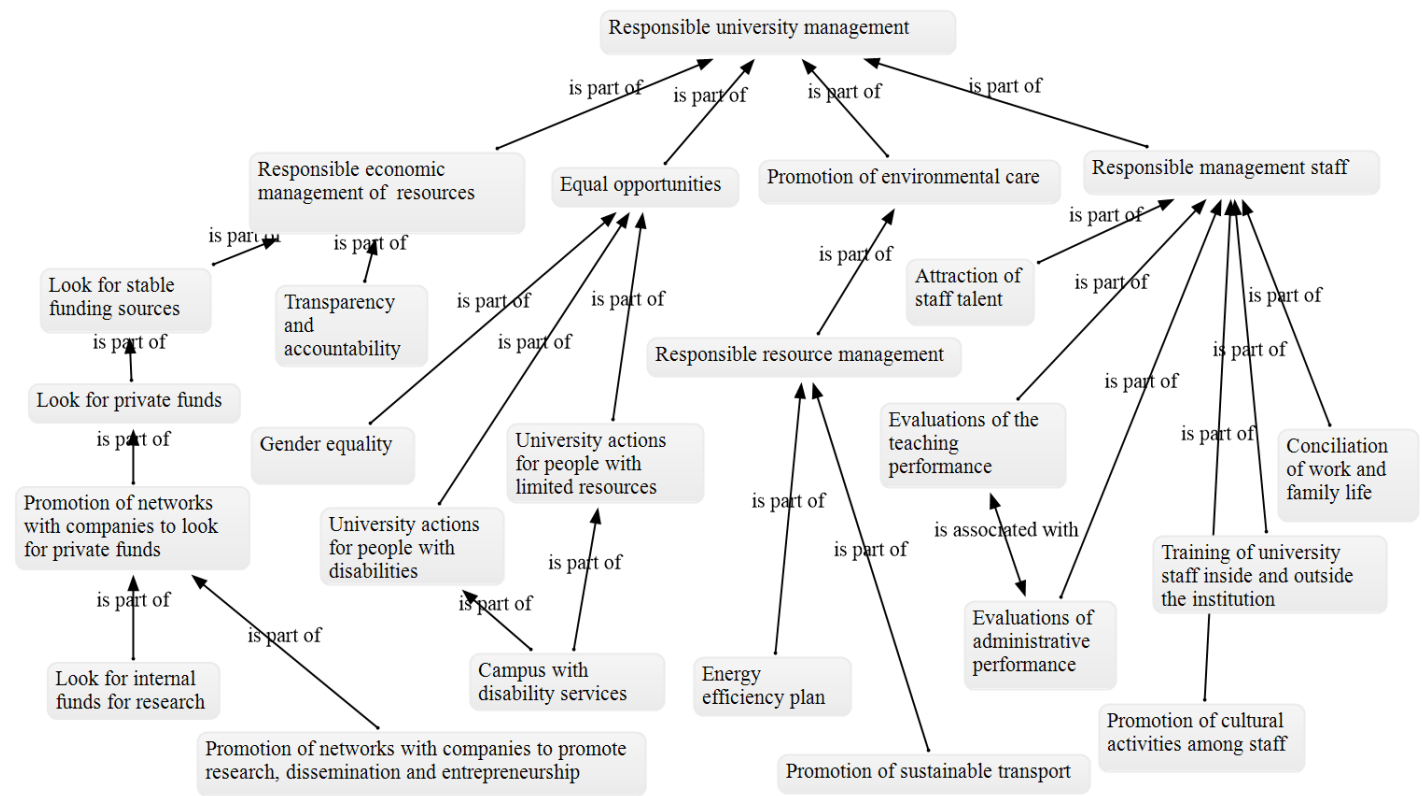

Figure 2.Semantic network of responsible university management and sub-catalysts. The top node of the figure is the dimension and their immediate offspring are the catalysts. The remaining nodes are considered sub-catalysts. 


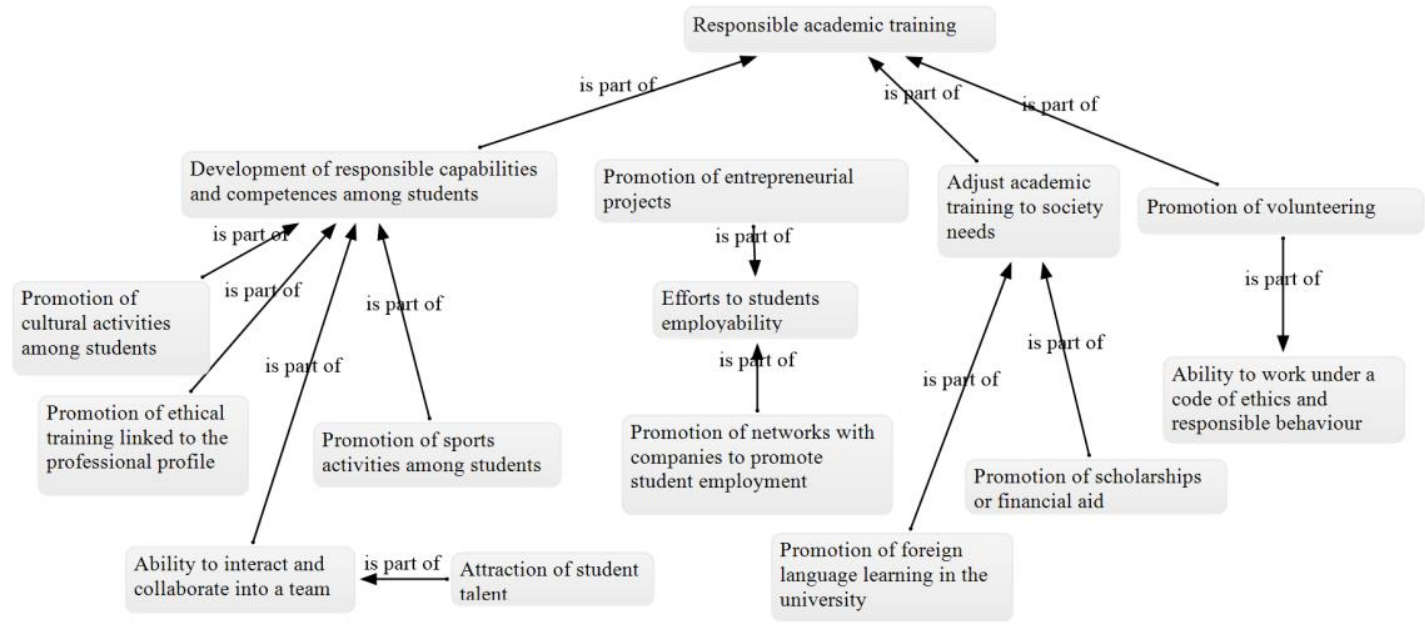

Figure 3.Semantic network of responsible academic training and sub-catalysts. The top node of the figure is the dimension and their immediate offspring are the catalysts. The remaining nodes are considered subcatalysts.

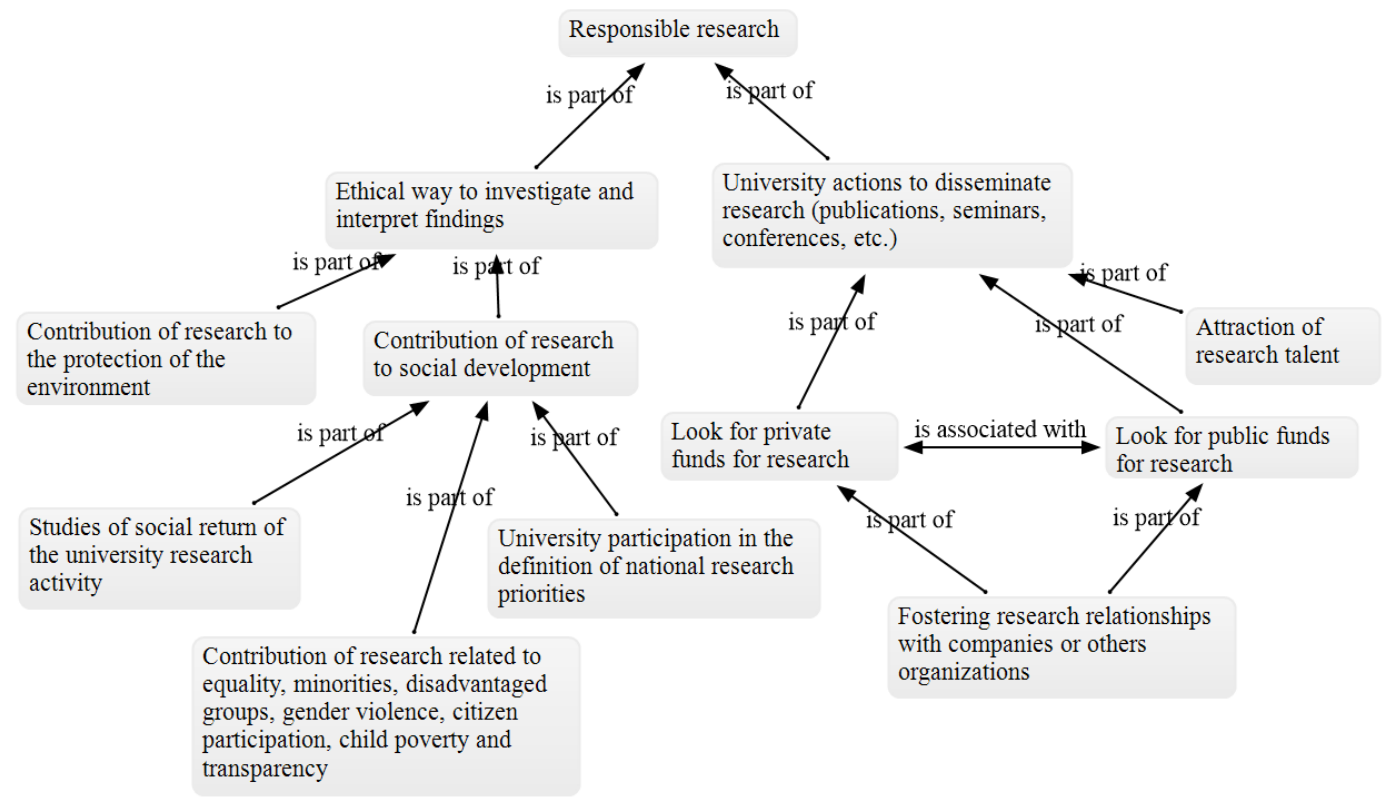

Figure 4.Semantic network of responsible research and sub-catalysts. The top node of the figure is the dimension and their immediate offspring are the catalysts. The remaining nodes are considered sub-catalysts. 


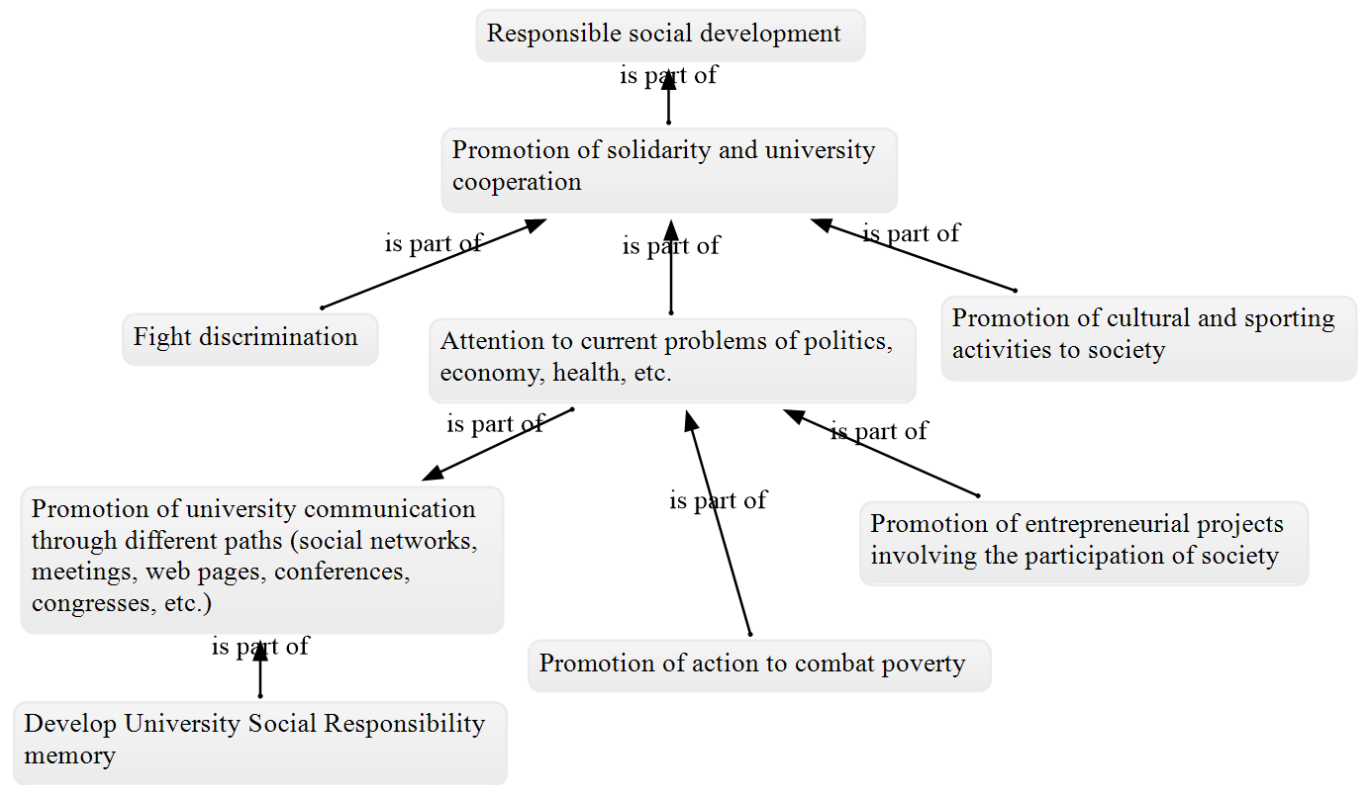

Figure 5.Semantic network of responsible social development and sub-catalysts. The top node of the figure is the dimension and their immediate offspring are the catalysts. The remaining nodes are considered subcatalysts. 


\begin{tabular}{|c|c|c|c|}
\hline $\begin{array}{l}\text { Spanish } \\
\text { University }\end{array}$ & Efforts to students entrepreneurship & $\begin{array}{l}\text { Spanish } \\
\text { University }\end{array}$ & Efforts to students entrepreneurship \\
\hline $\begin{array}{l}\text { Universitat de } \\
\text { València }\end{array}$ & $\begin{array}{l}\text { Projects and programs: } \\
\text {-Innovation, Valorization and } \\
\text { Entrepreneurship Section of the Research } \\
\text { and Innovation Service } \\
\text {-Science Park of the Universitat de } \\
\text { València } \\
\text {-Observatory of Professional Insertion and } \\
\text { Labor Advice (OPAL) } \\
\text {-University-Business Foundation of the } \\
\text { Universitat de València (ADEIT) } \\
\text { (Universitat de València 2017) }\end{array}$ & $\begin{array}{l}\text { Universidad } \\
\text { de Jaén }\end{array}$ & $\begin{array}{l}\text { Projects and programs: } \\
\text {-Technical advice to entrepreneurs and } \\
\text { self-employed } \\
\text {-Accompaniment of projects } \\
\text {-Promotion, information and } \\
\text { dissemination campaigns } \\
\text {-Business accommodation (pre- } \\
\text { incubation and incubation). } \\
\text { (Universidad de Jaén n.d.) }\end{array}$ \\
\hline $\begin{array}{l}\text { Universitat } \\
\text { Politècnica de } \\
\text { València }\end{array}$ & $\begin{array}{l}\text { Projects and programs: } \\
\text {-Integrated Employment Service } \\
\text {-Institute for the Creation and IDEAS } \\
\text {-Business Chairs Program } \\
\text {-Servipoli Foundation } \\
\text {-Globality and Microeconomics } \\
\text { Foundation } \\
\text { (Universitat Politècnica de València 2012) }\end{array}$ & $\begin{array}{l}\text { Universitat de } \\
\text { Barcelona }\end{array}$ & $\begin{array}{l}\text { Projects and programs: } \\
\text {-Barcelona Institut d'Emprenedoria, } \\
\text {-Conferences "Create a company? Why } \\
\text { not?" } \\
\text {-Yuzz / Explorer } \\
\text {-Consolidate Program } \\
\text {-From Science to the Market } \\
\text {-Emprèn UB Prize } \\
\text { (Universitat de Barcelona n.d.) }\end{array}$ \\
\hline $\begin{array}{l}\text { Universidade } \\
\text { de Santiago } \\
\text { de } \\
\text { Compostela }\end{array}$ & $\begin{array}{l}\text { Projects and programs: } \\
\text {-ARGOS Program } \\
\text {-Competition of Ideas and Business } \\
\text { Projects. } \\
\text {-Participation in the AKADEMIA } \\
\text {-Program organized by the Bankinter } \\
\text { Foundation. } \\
\text {-Training actions and talks in collaboration } \\
\text { cn Galicia Open Future, joint initiative of } \\
\text { Telefónica and the Xunta de Galicia. } \\
\text {-Advice and processing of applications to } \\
\text { obtain by business projects, qualification } \\
\text { as Technology Based Entrepreneurship } \\
\text {-Initiatives (IEBT) of the Consellería de } \\
\text { Traballo e Benestar. } \\
\text { (Universidade de Santiago de Compostela } \\
\text { n.d.) }\end{array}$ & $\begin{array}{l}\text { Universidad } \\
\text { de Salamanca }\end{array}$ & $\begin{array}{l}\text { Projects and programs: } \\
\text {-BINSAL Emprende } \\
\text {-Erasmus + } 2017 \text { "NICE" } \\
\text {-Interreg Poctep "UNI + i" } \\
\text {-Yuzz } \\
\text {-USAL Emprende } \\
\text { Technology-based entrepreneurship } \\
\text {-Telefónica Open Future } \\
\text {-Startup Europe Partnership (SEP) } \\
\text {-Lanzadera de Ideas Innovadoras } \\
\text {-T-CUE } \\
\text {-INESPO } \\
\text {-Social and Cultural Entrepreneurship } \\
\text { Week } \\
\text { (Universidad de Salamanca 2017) }\end{array}$ \\
\hline $\begin{array}{l}\text { Universitat } \\
\text { Pompeu } \\
\text { Fabra }\end{array}$ & $\begin{array}{l}\text { Projects and programs: } \\
\text {-Explorer Program 'Young people with } \\
\text { idea-Yuzz program } \\
\text {-UPFEmprèn Award } \\
\text {-Afternoon of Entrepreneurship } \\
\text {-Business Plan Guide } \\
\text {-Investment Forum } \\
\text {-HackLab } \\
\text {-Entrepreneurship Society } \\
\text { (Universitat Pompeu Fabra n.d.) }\end{array}$ & $\begin{array}{l}\text { Universidad } \\
\text { del Pais } \\
\text { Vasco }\end{array}$ & $\begin{array}{l}\text { Projects and programs: } \\
\text {-Classroom BIC-Entreprenarigunea } \\
\text {-Programa Entreprenari } \\
\text { (Universidad del Pais Vasco n.d.) }\end{array}$ \\
\hline $\begin{array}{l}\text { Universidade } \\
\text { da Coruña }\end{array}$ & $\begin{array}{l}\text { Projects and programs: } \\
\text {-Support to Spin-off as new mechanism of } \\
\text { transfer, more dynamic and active face } \\
\text { innovation } \\
\text {-Business Viveiro } \\
\text { (Universidade da Coruña n.d.) }\end{array}$ & $\begin{array}{l}\text { Universitat } \\
\text { Oberta de } \\
\text { Catalunya }\end{array}$ & $\begin{array}{l}\text { Projects and programs: } \\
\text {-Personal advice for entrepreneurs } \\
\text {-Hubbik, entrepreneurship accompanied } \\
\text { by a network of experts. } \\
\text { (Universitat Oberta de Catalunya n.d.) }\end{array}$ \\
\hline $\begin{array}{l}\text { Universidad } \\
\text { Pontificia de } \\
\text { Comillas }\end{array}$ & $\begin{array}{l}\text {-Support Program for Business Projects } \\
\text { (Universidad Pontificia de Comillas n.d.) }\end{array}$ & $\begin{array}{l}\text { Universidad } \\
\text { San Jorge }\end{array}$ & $\begin{array}{l}\text {-Emprender Foundation in Aragón } \\
\text {-Vivero GSV, "Vivero de } \\
\text { emprendedores CAI-Grupo San Valero" } \\
\text { (Universidad San Jorge 2016) }\end{array}$ \\
\hline $\begin{array}{l}\text { Universitat de } \\
\text { les Illes } \\
\text { Balears }\end{array}$ & $\begin{array}{l}\text { Projects and programs: } \\
\text {-Business creation program and Spin-off } \\
\text {-Services to entrepreneurs } \\
\text { (Universitat de les Illes Balears 2017) }\end{array}$ & $\begin{array}{l}\text { Universidad } \\
\text { de Alcalá }\end{array}$ & $\begin{array}{l}\text { Projects and programs: } \\
\text {-Entrepreneur personal skills } \\
\text {-Social and relational skills } \\
\text {-Organizational experience } \\
\text { (Universidad de Alcalá n.d.) } \\
\end{array}$ \\
\hline $\begin{array}{l}\text { Universidad } \\
\text { Loyola } \\
\text { Andalucía }\end{array}$ & $\begin{array}{l}\text { Projects and programs: } \\
\text {-Business project acceleration programs } \\
\text {-Training activities } \\
\text {-Round tables } \\
\text {-Mentoring program "Telemaco" } \\
\text {-Individual counseling service } \\
\text { (Universidad Loyola Andalucía n.d.) }\end{array}$ & $\begin{array}{l}\text { Universidad } \\
\text { de Alicante }\end{array}$ & $\begin{array}{l}\text { Projects and programs: } \\
\text {-Project ua:emprende } \\
\text {-"Campus del Emprenedor Innovador" } \\
\text { Program } \\
\text {-Explorer | The evolution of the } \\
\text { Santander YUZZ program } \\
\text { (Universidad de Alicante 2017) } \\
\end{array}$ \\
\hline $\begin{array}{l}\text { UNED | } \\
\text { Universidad } \\
\text { Nacional de }\end{array}$ & $\begin{array}{l}\text { Projects and programs: } \\
\text {-Business project planning and } \\
\text { management course }\end{array}$ & $\begin{array}{l}\text { Universidad } \\
\text { de Cantabria }\end{array}$ & $\begin{array}{l}\text { Projects and programs: } \\
\text {-Santander International } \\
\text { Entrepreneurship Center (CISE) }\end{array}$ \\
\hline
\end{tabular}




\begin{tabular}{|c|c|c|c|}
\hline $\begin{array}{l}\text { Educación a } \\
\text { Distancia }\end{array}$ & $\begin{array}{l}\text {-Center for Higher Studies on } \\
\text { Entrepreneurship } \\
\text { (UNED | Universidad Nacional de } \\
\text { Educación a Distancia n.d.) }\end{array}$ & & $\begin{array}{l}\text { Support services for entrepreneurship at } \\
\text { UC } \\
\text {-Leonardo Torres Quevedo Foundation } \\
\text {-Center for Technological Development } \\
\text { of the University of Cantabria (CDTUC) } \\
\text { (Universidad de Cantabria n.d.) }\end{array}$ \\
\hline $\begin{array}{l}\text { Universidad } \\
\text { de Deusto }\end{array}$ & $\begin{array}{l}\text { Projects and programs: } \\
\text {-Deusto Entrepreneurship Centre } \\
\text {-DeustoSTART Corporate } \\
\text {-DeustoPush } \\
\text {-Deusto Digital Accelerate } \\
\text {-Yuzz program } \\
\text {-DeustoKabi-Inubator } \\
\text { (Universidad de Deusto 2017) }\end{array}$ & $\begin{array}{l}\text { Universidad } \\
\text { de la Rioja }\end{array}$ & $\begin{array}{l}\text { Projects and programs: } \\
\text {-Cátedra de Emprendedores } \\
\text { (Universidad de la Rioja n.d.) }\end{array}$ \\
\hline $\begin{array}{l}\text { Universidad } \\
\text { de Cádiz }\end{array}$ & $\begin{array}{l}\text { Projects and programs: } \\
\text {-Chair of Entrepreneurs of the University } \\
\text { of Cádiz } \\
\text {-Entrepreneur Network UCA } \\
\text {-INTREPIDED PROJECT: Spain Portugal } \\
\text { Cross Border Cooperation Program } \\
\text { (POCTEP). } \\
\text { (Universidad de Cádiz n.d.) }\end{array}$ & $\begin{array}{l}\text { Universidad } \\
\text { de } \\
\text { Extremadura }\end{array}$ & $\begin{array}{l}\text { Projects and programs: } \\
\text {-SAPIEM: The Support Service for the } \\
\text { Entrepreneurship Initiative of the } \\
\text { University of Extremadura } \\
\text {-Programa YUZZ: } \\
\text { (Universidad de Extremadura n.d.) }\end{array}$ \\
\hline $\begin{array}{l}\text { Universidad } \\
\text { de Las } \\
\text { Palmas de } \\
\text { Gran Canaria }\end{array}$ & $\begin{array}{l}\text { Projects and programs: } \\
\text {-Chair for Young Entrepreneurs } \\
\text {-Competition for pre-university } \\
\text { entrepreneurs } \\
\text { (Universidad de Las Palmas de Gran } \\
\text { Canaria 2016) }\end{array}$ & & \\
\hline
\end{tabular}

Table 9.Entrepreneurial activities into university 